\title{
Processing and Characterization of Silicon Nitride Bioceramics
}

Bryan J. McEntire ${ }^{1 *}$, Ramaswamy Lakshminarayanan², Prabhakar Thirugnanasambandam ${ }^{3}$, Jacob Seitz-Sampson ${ }^{1}$, Ryan Bock $^{1}$ and David O'Brien ${ }^{1}$

${ }^{1}$ Amedica Corporation, 1885 West 2100 South, Salt Lake City, UT 84119

${ }^{2}$ Corning, Inc., SP-FR-04, Corning, NY 14831

${ }^{3}$ Prismatik Dentalcraft, Inc., 2181 Dupont Dr., Irvine, CA 92612

\begin{abstract}
As a relatively new biomaterial, silicon nitride $\left(\mathrm{Si}_{3} \mathrm{~N}_{4}\right)$ is currently used as an arthrodesis device in the cervical and thoracolumbar spine, and it is under consideration as a bearing material in total joint arthroplasty. In this paper, the development and validation of the manufacturing processes used in the production of $\mathrm{Si}_{3} \mathrm{~N}_{4}$ biomedical implants are presented and discussed. Manufacturing was conducted in a facility specifically dedicated for this purpose using processes designed to yield net shape intervertebral spinal spacers by conventional dry-pressing, CNC machining of components in the green state, sintering, and hot isostatic pressing. These manufacturing methods were industrialized using Taguchi fractional factorial experimental designs, followed by implementation of statistical process controls. The roles of various processing parameters including raw materials, pressing, and firing conditions (i.e., time, temperature, and pressure) are elucidated. For these devices, it was demonstrated that acceptable physical, mechanical, and dimensional properties were consistently obtained from carefully designed and statistically controlled processes.
\end{abstract}

Keywords: Bioceramic; Process validation; Silicon nitride; Taguchi methods

\section{Introduction}

Silicon nitride $\left(\mathrm{Si}_{3} \mathrm{~N}_{4}\right)$ is a relatively new man-made material. Synthesized in 1859, it was first manufactured into useful refractory shapes in the 1950s-60s, but was not extensively developed as an engineered ceramic until the 1980s [1-4]. Since then, it has garnered considerable attention because of its unique combination of excellent room- and high-temperature mechanical strength, toughness, oxidation, and thermal shock resistance $[1,5-15] . \mathrm{Si}_{3} \mathrm{~N}_{4}$ is currently used in demanding mechanical applications involving high loads, wear, and corrosion [16]. However, until recently, it was not widely considered appropriate for medical devices. Early researchers erroneously assumed that $\mathrm{Si}_{3} \mathrm{~N}_{4}$ was not biocompatible in spite of a lack of adverse biologic reactions during long-term in vivo exposure [1720]. Also, $\mathrm{Si}_{3} \mathrm{~N}_{4}$ was considered to be an exotic expensive raw material requiring difficult fabrication steps. Conversely, oxide-based ceramics including alumina $\left(\mathrm{Al}_{2} \mathrm{O}_{3}\right)$, zirconia $\left(\mathrm{ZrO}_{2}\right)$, and zirconia-toughenedalumina (ZTA), were presumed to be less expensive than $\mathrm{Si}_{3} \mathrm{~N}_{4}$. Although they were developed earlier and are now extensively used in total joint arthroplasty, processing of medical devices from oxide ceramics utilizes similar manufacturing equipment and process steps as $\mathrm{Si}_{3} \mathrm{~N}_{4}$ and their respective raw material costs do not differ substantially [21-23]. Finally, it was believed that oxide ceramics $\left(\mathrm{ZrO}_{2}\right.$ and ZTA in particular) provided improved performance over their non-oxide counterparts. However, in terms of strength and toughness, $\mathrm{Si}_{3} \mathrm{~N}_{4}$ has comparable properties to medical-grade $\mathrm{ZrO}_{2}$ or $\mathrm{ZTA}$, and it is $\sim 2-3$ times superior to medical-grade $\mathrm{Al}_{2} \mathrm{O}_{3}$ [24]. In addition to high strength and fracture toughness, $\mathrm{Si}_{3} \mathrm{~N}_{4}$ has other unique properties that make it attractive for demanding orthopaedic applications including inherent phase stability, low wear, scratch resistance, hydrophilicity, improved radiographic imaging, and bacteriostasis [25]. It has been cleared by the US FDA and EU regulatory agencies for implantation as intervertebral spacers for stabilization of the cervical and thoracolumbar spine. It is also being developed for reconstructive applications (i.e., hip and knee arthroplasty) but has yet to receive regulatory clearance for these purposes. A photograph of current and future implantable medical devices made from $\mathrm{Si}_{3} \mathrm{~N}_{4}$ is shown in (Figure 1). Manufacturing of these devices has been performed in a dedicated production facility specifically engineered for this purpose. In accordance with current good manufacturing practice (cGMP) regulatory guidelines, both the facility and the fabrication processes were subjected to rigorous validations [26]. Presented within this paper are summarized results of these validation studies for $\mathrm{Si}_{3} \mathrm{~N}_{4}$ biomedical implants.

\section{Materials and Methods}

\section{Raw materials}

The overall silicon nitride composition was fixed (i.e., $6 \mathrm{wt} . \%$ $\mathrm{Y}_{2} \mathrm{O}_{3}, 4$ wt.\% $\mathrm{Al}_{2} \mathrm{O}_{3}, 90 \mathrm{wt} . \% \mathrm{Si}_{3} \mathrm{~N}_{4}$ ), but it is similar to commonly developed and currently used silicon nitrides in industrial applications [27-29]. Two sources of silicon nitride raw powder were examined within the validation study: Ube SN-E10 (Ube Industries, Tokyo, Japan) and Starck M11 HP (H. C. Starck, Goslar, Germany). Their respective material specifications are provided in (Table 1). Note that the properties of these two silicon nitrides are quite similar, but their

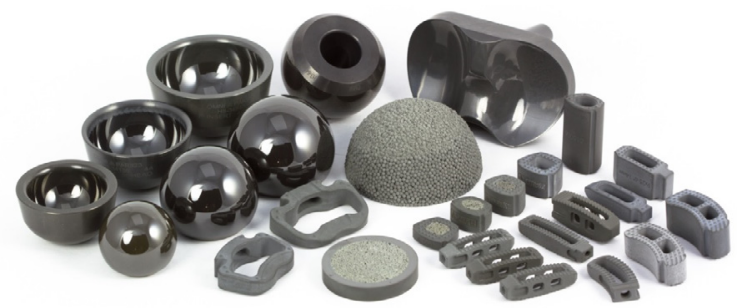

Figure 1: Representative spinal and reconstructive implants produced from biomedical $\mathrm{Si}_{3} \mathrm{~N}_{4}$. (Courtesy: Amedica Corporation.)

*Corresponding authors: Bryan J McEntire, Chief Technology Officer, Amedica Corporation, 1885 West 2100 South, Salt Lake City, UT 84119, USA, Tel: 8018393504; E-mail: bmcentire@amedica.com

Received April 25, 2016; Accepted May 23, 2016; Published May 30, 2016

Citation: McEntire, BJ et al. (2016) Processing and Characterization of Silicon Nitride Bioceramics. Bioceram Dev Appl 6: 093. doi:10.4172/2090-5025.100093

Copyright: (c) 2016 McEntire BJ, et al. This is an open-access article distributed under the terms of the Creative Commons Attribution License, which permits unrestricted use, distribution, and reproduction in any medium, provided the original author and source are credited. 


\begin{tabular}{|c|c|c|}
\hline Properties & SN E10 & M11 HP \\
\hline $\mathrm{N}(\mathrm{wt} . \%)$ & $>38.0$ & $>38.5$ \\
\hline $\mathrm{O}(\mathrm{wt} . \%)$ & $<2.0$ & $<1.5$ \\
\hline $\mathrm{C}(\mathrm{wt} . \%)$ & $<0.2$ & $<0.2$ \\
\hline $\mathrm{Cl}(\mathrm{ppm})$ & $<100$ & $\mathrm{~N} / \mathrm{A}$ \\
\hline $\mathrm{Fe}(\mathrm{ppm})$ & $<100$ & $<10$ \\
\hline $\mathrm{Ca}(\mathrm{ppm})$ & $<50$ & $<10$ \\
\hline $\mathrm{Al}(\mathrm{ppm})$ & $<50$ & $<50$ \\
\hline $\mathrm{Co}(\mathrm{ppm})$ & $\mathrm{N} / \mathrm{A}$ & $<50$ \\
\hline $\mathrm{Cu}(\mathrm{ppm})$ & $\mathrm{N} / \mathrm{A}$ & $<50$ \\
\hline B/( $\alpha+ß)(w t . \%)$ & $<5$ & $<10$ \\
\hline Particle Size $(\mu \mathrm{m})$ & 12.2 & 15.7 \\
\hline D90 & & 1.77 \\
\hline D50 & 1.2 & 1.16 \\
\hline D10 & 0.52 & 0.67 \\
\hline
\end{tabular}

Table 1: Physicochemical properties of $\mathrm{Si}_{3} \mathrm{~N}_{4}$ raw materials.

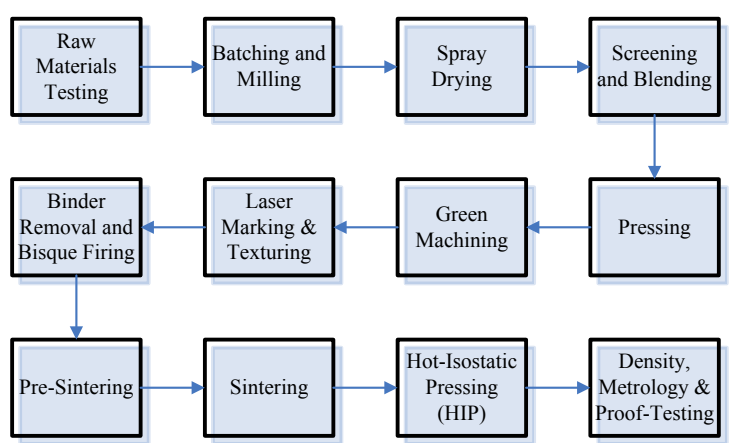

Figure 2: Manufacturing process flow diagram for production of biomedical intervertebral spinal spacers from $\mathrm{Si}_{3} \mathrm{~N}_{4}$.

synthesis methods differ considerably. Ube SN-E10 is prepared from high purity silicon diamide and ammonia, whereas Starck M-11 HP is prepared by nitriding silicon metal. The other two major inorganic raw materials were $\mathrm{Y}_{2} \mathrm{O}_{3}$ (Grade C, H. C. Starck, Goslar, Germany) and $\mathrm{Al}_{2} \mathrm{O}_{3}$ (Baikowski XRC-UFX-MAR, Malakoff, TX USA).

\section{Manufacturing processes}

A flow diagram of the $\mathrm{Si}_{3} \mathrm{~N}_{4}$ manufacturing operations for spinal fusion devices is shown in (Figure 2). Batching involved accurately weighing appropriate amounts of each raw material along with deionized water, dispersants, binders. These constituents were charged into attrition mills (Q2 and Q6 Attritors, Union Process, Akron, $\mathrm{OH}$ USA) equipped with high purity (99.95\%) $\mathrm{Si}_{3} \mathrm{~N}_{4}$ milling media [30]. Following milling, spray drying was performed using standard industrial dryers (Mobile Minor and SD-6.3, GEA Niro, Søborg, Denmark) to convert the liquid slurry to a dry powder [31]. After spray drying, classification of the spray dried powder was performed by passing the material through vibratory screen separators (Sweco ZS24, Florence, KY USA). The classified powder was then blended with a press lubricant in a twin shell V-blender (Laboratory Model, PattersonKelly, East Stroudsburg, PA USA). Dry-pressing of the conditioned spray dried powder was the next process step [32,33]. Uniaxial and isostatic equipment (TPA-30, Dorst America, Bethlehem, PA, USA, and CP-083, Avure Technologies, Columbus, $\mathrm{OH}$, USA, respectively) were used for this purpose at pressures ranging from $\sim 100 \mathrm{MPa}$ to $\sim 300$ $\mathrm{MPa}$. Pressure was adjusted for each powder lot to obtain a targeted green density and linear shrinkage. Typically, green densities in excess of $50 \%$ were generally required to effectively achieve densification during firing. Green machining of the pressed blanks was subsequently performed using programmed $\mathrm{CNC}$ vertical machining or turning centers (OM1, VF2, and OL1, Haas Automation, Oxnard, CA, USA) [34]. Laser etching and engraving of the machined components were performed next using high-powered Nd-YAG equipment (FOBA G5 Laser Marker, Alltec GmbH, Selmsdorf, Germany). These operations provide the green ceramic with a rough surface to ultimately aid in osseointegration of the spinal spacer, and to mark each component with lot and part numbers for regulatory traceability. Organic additives were decomposed and removed from the ceramic during a thermal treatment in batch kilns. This operation was performed either in air or in $\mathrm{N}_{2}$ (ModelCESVN06, Thermal Tek, Concord, North Carolina, USA, or Model 121224, Centorr Vacuum Industries, Nashua, NH, USA, respectively). For air-firing, temperatures did not exceed about $750^{\circ} \mathrm{C}$ to prevent reactive decomposition of the ceramic [35]. Decomposition is obviously suppressed when firing in nitrogen. In either case, organic compounds were decomposed and removed at temperatures between about $450^{\circ} \mathrm{C}$ to $600^{\circ} \mathrm{C}$ for time periods of about 2 hours. Subsequent to binder removal, parts were subjected to higher temperature bisque firing in nitrogen at temperatures up to $1200^{\circ} \mathrm{C}$ for 1 to 2 hours. Presintering of the $\mathrm{Si}_{3} \mathrm{~N}_{4}$ was the next firing step. All $\mathrm{Si}_{3} \mathrm{~N}_{4}$ raw materials contain a certain amount of oxygen as a native impurity, generally less than about $2 \%$, in the form of silicon-dioxide $\left(\mathrm{SiO}_{2}\right)$. During high temperature firing, some of this oxygen is converted to siliconmonoxide $(\mathrm{SiO})$ gas. While researchers have determined that oxygen is necessary to obtain appropriate densification and high strength, too much oxygen can degrade properties [36]. Removal of excess $\mathrm{SiO}_{2}$ during pre-sintering decreases the amount of the intergranular glass phase, which has a resultant beneficial effect on mechanical properties [37]. In an oxygen depleted environment or in the presence of carbon, silicon-monoxide gas, $\mathrm{SiO}(\mathrm{g})$, is generated in accordance with the following series of reactions [38-43].

$$
2 \mathrm{Si}_{3} \mathrm{~N}_{4}(\mathrm{~s})+3 \mathrm{O}_{2}(\mathrm{~g}) \rightarrow 6 \mathrm{SiO}(\mathrm{g})+4 \mathrm{~N}_{2}(\mathrm{~g})
$$

This reaction (i.e., Equation 1) occurs under reducing conditions when residual oxygen is present.

$$
\begin{aligned}
& 2 \mathrm{SiO}_{2}(\mathrm{~s}) \rightarrow 2 \mathrm{SiO}(\mathrm{g})+\mathrm{O}_{2}(\mathrm{~g}) \\
& 2 \mathrm{Si}_{3} \mathrm{~N}_{4}(\mathrm{~s})+3 \mathrm{O}_{2}(\mathrm{~g}) \rightarrow 6 \mathrm{SiO}(\mathrm{g})+4 \mathrm{~N}_{2}(\mathrm{~g}) \\
& \mathrm{Si}_{3} \mathrm{~N}_{4}(\mathrm{~s})+3 \mathrm{SiO}_{2}(\mathrm{~s}) \rightarrow 6 \mathrm{SiO}(\mathrm{g})+2 \mathrm{~N}_{2}(\mathrm{~g})
\end{aligned}
$$

The foregoing reactions (i.e., Equation 2) occur under reducing conditions when $\mathrm{SiO}_{2}$ is present; and the next series of reactions (i.e., Equation 3) are possible under reducing conditions when carbon is present.

$$
\begin{aligned}
& 2 \mathrm{SiO}_{2}(\mathrm{~s}) \rightarrow 2 \mathrm{SiO}(\mathrm{g})+\mathrm{O}_{2}(\mathrm{~g}) \\
& 2 \mathrm{C}(\mathrm{s})+\mathrm{O}_{2}(\mathrm{~g}) \rightarrow 2 \mathrm{CO}(\mathrm{g}) \\
& \mathrm{SiO}_{2}(\mathrm{~s})+\mathrm{C}(\mathrm{s}) \rightarrow \mathrm{SiO}(\mathrm{g})+\mathrm{CO}(\mathrm{g}) \\
& \mathrm{CO}(\mathrm{g})+\mathrm{SiO}(\mathrm{g}) \rightarrow \mathrm{SiC}(\mathrm{s})+\mathrm{O}_{2}(\mathrm{~g}) \\
& \mathrm{SiO}_{2}(\mathrm{~s})+\mathrm{C}(\mathrm{s}) \rightarrow \mathrm{SiC}(\mathrm{s})+\mathrm{O}_{2}(\mathrm{~g}) \\
& 2 \mathrm{Si}_{3} \mathrm{~N}_{4}(\mathrm{~s})+3 \mathrm{O}_{2}(\mathrm{~g}) \rightarrow 6 \mathrm{SiO}(\mathrm{g})+4 \mathrm{~N}_{2}(\mathrm{~g}) \\
& 2 \mathrm{Si}_{3} \mathrm{~N}_{4}(\mathrm{~s})+3 \mathrm{C}(\mathrm{s})+3 \mathrm{SiO}_{2}(\mathrm{~s}) \rightarrow 3 \mathrm{SiC}(\mathrm{s})+6 \mathrm{SiO}(\mathrm{g})+4 \mathrm{~N}_{2}(\mathrm{~g})
\end{aligned}
$$

Pre-sintering was generally conducted at temperatures between $1400^{\circ} \mathrm{C}$ and $1600^{\circ} \mathrm{C}$ for up to 2 hours. Sintering was the next, and perhaps the most important firing step. Densification and the 
irreversible $\alpha \rightarrow$ phase transformation simultaneously occurred during this heat-treatment cycle [44]. The microstructure of the material evolved from equiaxed primary a-phase particles and $\sim 50 \%$ open porosity to interlocking needle-like $\beta$-phase grains and $<5 \%$ closed porosity $[45,46]$. Components were fired in nitrogen in a batch furnace with a slight $\mathrm{N}_{2}$ overpressure $(+13.7 \mathrm{kPa})$, or in a continuous furnace at ambient pressure under flowing $\mathrm{N}_{2}$ (Centorr Vacuum Industries, Nashua, NH, USA), or in a hot-isostatic press (HIP) (QIH-21 Avure Technologies Columbus, $\mathrm{OH}$ ) at pressures ranging from about 0.7 $\mathrm{MPa}$, to $10 \mathrm{MPa}$. After sintering components to closed porosity, hot-isostatic pressing (HIPing) was performed to remove residual pores from the fired bodies and to coarsen the $\beta-\mathrm{Si}_{3} \mathrm{~N}_{4}$ grains within the microstructure. Coarsening improves their interlocking behavior which translates to increased fracture toughness. The sintering and HIPing conditions explored within this study included temperatures of between $1650^{\circ} \mathrm{C}$ to $1800^{\circ} \mathrm{C}$, times of up to 3 hours, and pressures between $\sim 100 \mathrm{MPa}$ and $\sim 200 \mathrm{MPa}$.

At the end of the process, components were inspected for density by an Archimedes method (i.e., ASTM C-373) using a typical analytical balance (XS205, Metler Toledo, Columbus, OH, USA). They were then proof-tested in specially designed fixtures using a compression testing machine (5567, Instron, Norwood, MA, USA). Proof-testing involved axially loading each part to a pre-determined limit based on finite element analyses or other analytical or empirical methods. Proof-testing has been effectively used to eliminate defective components in other biomedical ceramics [47]. Following prooftesting, a detailed microscopic visual inspection was conducted, (Stereomicroscopes, Zeiss Inc., Ontario, CA, USA), which in turn was followed by dimensional inspection using either a semi-automated visual measuring system (Smartscope MVP 200, OGP, Rochester, NY) or a coordinate measuring machine (CMM, Contura, Zeiss, Brighton, MI, USA). Mechanical testing was performed using standard test bars ( $3 \mathrm{~mm} \times 4 \mathrm{~mm} \times 45 \mathrm{~mm}$ ) in accordance with ASTM C-1161 and ASTM E-399 for 3-pt. flexural and fracture toughness measurements, respectively. Scanning electron microscopy (SEM) was carried out using a field emission gun scanning electron microscope (FEG-SEM) (Quanta, FEI, Hillsboro, OR, USA). All samples were sputter-coated (108 auto, Cressington, Watford, UK) with a thin ( 20 to 30 $)$ layer of gold. Samples were imaged using an accelerating voltage of $10 \mathrm{kV}$ at working distances of 7-10 $\mathrm{mm}$ and spot sizes of 4-5 mm. Analysis of variance was utilized to determine statistical significance for all measureable physical and mechanical properties, using sample sizes of $\mathrm{n} \geq 5$ for density measurements and $\mathrm{n} \geq 20$ for strength determination.

\section{Process validation methodology}

While effective process validations address every vital step of the manufacturing process, from a practical standpoint, the effort is typically limited to the most critical process parameters (CPPs, i.e., those having the greatest impact on the safety or efficacy of the finished medical device). An assessment of the $\mathrm{Si}_{3} \mathrm{~N}_{4}$ manufacturing process indicated that there were 14 major steps, with $\sim 45$ potential CPPs, and +80 possible alternative conditions. Clearly, this was too many to be easily and systematically evaluated within the validation study. Consequently, a process failure modes and effects analysis (PFMEA) was performed to down select and rank only those CPPs considered to be most important [48]. Its completion resulted in the following prioritized production operations and parameters requiring detailed investigation:

(1) Raw materials $-\mathrm{Si}_{3} \mathrm{~N}_{4}$
(2) Pressing - pressure

(3) Pre-sintering - temperature and time

(4) Sintering - temperature and time

(5) HIPing - temperature, time, and pressure.

The remaining parameters were pre-determined and held constant based on prior industrial experience, peer reviewed literature, or from small Taguchi fractional factorial screening experiments [49]. Larger Taguchi experiments were then designed and conducted to evaluate and correlate interactions between the selected CPPs [50]. Taguchi experimental designs and methodologies are particularly efficient in determining important parameters, and in robustly controlling manufacturing processes $[51,52]$.

\section{Results and Discussion}

\section{Process validation studies}

Following several screening experiments, a number of larger surface response studies were designed and conducted. These were directed at exploring interactive effects between the identified CPPs. Two of the studies are presented here as examples:

(1) An $L_{8}$ study correlating raw material, pre-sintering, and sintering conditions.

(2) An $\mathrm{L}_{18}$ study testing the effects of binder composition, HIPing, and sintering conditions.

The experimental designs for these two studies and results are shown in Tables $2 \mathrm{a}$ and $3 \mathrm{a}$, respectively, with their corresponding ANOVAs presented in Tables $2 \mathrm{~b} \sim 2 \mathrm{c}$ and $3 \mathrm{~b} \sim 3 \mathrm{c}$, respectively. For each experiment, standard flexural test bars were prepared and characterized for density and flexural strength. Analyses of Variance (ANOVA) were then conducted to determine the significance of the results using F-statistics at $\mathrm{p}$ values $\leq 0.05$.

For the $\mathrm{L}_{8}$ design, the results provide an interesting comparison between the two $\mathrm{Si}_{3} \mathrm{~N}_{4}$ raw materials. There appeared to be substantial benefit from using Ube SN-E10 over Starck M11-HP in the chosen validation range. While the best HIPed densities of the two materials were essentially equivalent, strength results were $\sim 240 \mathrm{MPa}$ higher when using Ube SN-E10. The best average strength obtained using Starck M11-HP was $\sim 750 \mathrm{MPa}$, whereas the best data from Ube SNE10 was $\sim 1,075 \mathrm{MPa}$. Note that Ube SN-E10 has a much broader processing window, particularly with respect to sintering temperature. The range of HIPed densities for SN-E10 was between 3.243 and $3.259 \mathrm{~g} / \mathrm{cc}$, (range of 0.016), whereas Starck M11-HP provided data between 3.201 and $3.256 \mathrm{~g} / \mathrm{cc}$ (range of 0.055 ). Theoretical density for these compositions was calculated to be $3.271 \mathrm{~g} / \mathrm{cc}$ based on the rule of mixtures. Consequently, observed data ranged from $97.86 \%$ to $99.54 \%$ of this theoretical value. Differences between maximum and minimum HIPed densities for the Ube SN-E10 and Starck M-11 materials were less than $1.74 \%$. The corresponding average strengths for Ube SN-E10 ranged from $994 \mathrm{MPa}$ to $1,090 \mathrm{MPa}$ (range $96 \mathrm{MPa}$ ) whereas Starck M-11HP ranged from $611 \mathrm{MPa}$ to $748 \mathrm{MPa}$ (range of $137 \mathrm{MPa}$; (Table 2a). For sintered density, all four experimental factors were statistically significant within the $\mathrm{L}_{8}$ ANOVA, but the greatest contribution came from the raw material source, followed by sintering time, then pre-sinter condition, and finally sintering temperature ( $c f$., Table $2 \mathrm{~b}$ ). The observation that sintering time is a more important variable than temperature is desirable from a processing viewpoint. Time can be precisely determined and controlled, whereas temperature 
Citation: McEntire, BJ et al. (2016) Processing and Characterization of Silicon Nitride Bioceramics. Bioceram Dev Appl 6: 093. doi:10.4172/20905025.100093

Page 4 of 9

\begin{tabular}{|c|c|c|c|c|c|c|}
\hline $\begin{array}{c}\text { Raw } \\
\text { Material }\end{array}$ & Pre-Sinter & $\begin{array}{l}\text { Sintering } \\
\text { Temp. }\end{array}$ & $\begin{array}{l}\text { Sintering } \\
\text { Time }\end{array}$ & $\begin{array}{c}\text { Sintered } \\
\text { Density (g/cc) }\end{array}$ & $\begin{array}{c}\text { HIPed } \\
\text { Density (g/cc) }\end{array}$ & $\begin{array}{l}\text { Flexural Strength } \\
(\mathrm{MPa})\end{array}$ \\
\hline \multirow{4}{*}{ Starck M11-HP } & \multirow{2}{*}{ On } & Low & Short & $3.086 \pm 0.008$ & $3.202 \pm 0.007$ & $611 \pm 52$ \\
\hline & & High & Long & $3.202 \pm 0.009$ & $3.256 \pm 0.005$ & $748 \pm 143$ \\
\hline & \multirow{2}{*}{ Off } & Low & Long & $3.123 \pm 0.005$ & $3.213 \pm 0.012$ & $623 \pm 108$ \\
\hline & & High & Short & $3.069 \pm 0.012$ & $3.201 \pm 0.010$ & $639 \pm 88$ \\
\hline \multirow{4}{*}{ Ube SN-E10 } & \multirow{2}{*}{ On } & Low & Short & $3.171 \pm 0.014$ & $3.251 \pm 0.002$ & $1,050 \pm 147$ \\
\hline & & High & Long & $3.225 \pm 0.013$ & $3.259 \pm 0.006$ & $994 \pm 148$ \\
\hline & \multirow{2}{*}{ Off } & Low & Long & $3.187 \pm 0.007$ & $3.251 \pm 0.004$ & $1,090 \pm 150$ \\
\hline & & High & Short & $3.168 \pm 0.011$ & $3.243 \pm 0.003$ & $1,076 \pm 149$ \\
\hline
\end{tabular}

Table 2a: Taguchi $L_{8}$ experiment examining the effects of raw material, pre-sinter condition, sintering temperature and time on physical and mechanical properties of biomedical $\mathrm{Si}_{3} \mathrm{~N}_{4}$

\begin{tabular}{|c|c|c|c|c|c|c|}
\hline Source & SS & df & MS & $\mathbf{F}$ & $\mathbf{P}$ & $\%$ Contribution \\
\hline Raw Mat'I & 0.2557 & 1 & 0.25569 & 2400.629 & 0 & $40.49 \%$ \\
\hline Sinter Temp & 0.0328 & 1 & 0.03283 & 308.27 & 0 & $5.20 \%$ \\
\hline Sinter Time & 0.2056 & 1 & 0.20565 & 1930.776 & 0 & $32.57 \%$ \\
\hline Pre-Sinter & 0.0664 & 1 & 0.0664 & 623.437 & 0 & $10.52 \%$ \\
\hline$A B$ & 0.0029 & 1 & 0.00285 & 26.765 & 0 & $0.45 \%$ \\
\hline$A C$ & 0.0336 & 1 & 0.03362 & 315.678 & 0 & $5.32 \%$ \\
\hline$A D$ & 0.0114 & 1 & 0.01144 & 107.417 & 0 & $1.81 \%$ \\
\hline Error & 0.023 & 216 & 0.00011 & & & $3.64 \%$ \\
\hline Total & 0.6315 & 223 & & & & \\
\hline
\end{tabular}

Table 2b: Taguchi L8 ANOVA for sintered density.

\begin{tabular}{|c|c|c|c|c|c|c|}
\hline Source & ss & df & MS & $\mathbf{F}$ & $\mathbf{P}$ & $\%$ Contribution \\
\hline Raw Mat'I & 8833941 & 1 & 8833941 & 647.025 & 0 & $72.00 \%$ \\
\hline Sinter Temp & 23206.7 & 1 & 23206.7 & 1.7 & 0.194 & $0.19 \%$ \\
\hline Sinter Time & 23074.2 & 1 & 23074.2 & 1.69 & 0.195 & $0.19 \%$ \\
\hline Pre-Sinter & 2569.8 & 1 & 2569.8 & 0.188 & 0.665 & $0.02 \%$ \\
\hline$A B$ & 174298.5 & 1 & 174298.5 & 12.766 & 0 & $1.42 \%$ \\
\hline$A C$ & 90398.6 & 1 & 90398.6 & 6.621 & 0.011 & $0.74 \%$ \\
\hline$A D$ & 172624.5 & 1 & 172624.5 & 12.644 & 0 & $1.41 \%$ \\
\hline Error & 2949084 & 216 & 13653.17 & & & $24.04 \%$ \\
\hline Total & 12269198 & 223 & & & & \\
\hline
\end{tabular}

Table 2c: Taguchi L8 ANOVA for flexural strength.

fluctuations of up to $\pm 40^{\circ} \mathrm{C}$ may occur, but will likely still produce a quality product. The $\mathrm{L}_{8}$ ANOVA for flexural strength indicated that the only governing factor was raw material ( $c f$. Table $2 c$ ). All other variables were insignificant when compared with experimental error. SEM photographs of contrasting microstructures for the two raw materials processed under identical conditions are shown in Figures $3 \mathrm{a}$ and $3 \mathrm{~b}$. While quantitative analyses of grain size and distribution were not performed, differences in mechanical properties between the Ube SN-E10 and Starck M-11 compositions were self-evident from their respective microstructures ( $c f$., Figures $3 \mathrm{a}$ and $3 \mathrm{~b}$ ). The estimated average grain size for the Starck M-11 composition was approximately $2 \mathrm{x}$ that of the comparable Ube SN-E10 composition, which is the principal reason for its lower strength [11]. It is believed that the agglomerated nature of the Starck M-11 powder was the reason for the larger observed grain size (cf., Table 1). Even though it had an intrinsic surface area that was comparable to the SN-E10 powder ( $c f$., Table 1), the M11 raw material required extensive milling to reduce it to its primary particles. Under comparable milling conditions, the Ube powder proved to be superior. However, it has also been shown that powders possessing higher starting $\beta$-phase contents can also cause exaggerated grain growth, which results in lower strengths [53]. Based on the output of this $\mathrm{L}_{8}$ study, preferred conditions for raw material, pre-sintering, sintering time, and temperature included use
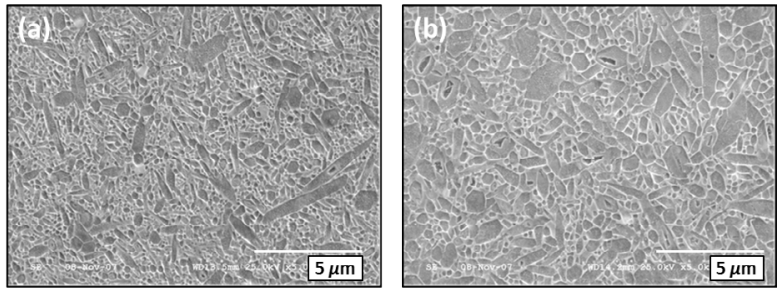

Figure 3: Representative microstructures of dense $\mathrm{Si}_{3} \mathrm{~N}_{4}$ prepared using different raw materials under the following conditions: Pre-sinter - off; Sintering temperature - low; Sintering time - long; (a) Ube SN-E10 and (b) Starck M11-HP.

of Ube SN-E10 powder, incorporation of a pre-sintering step, and sintering at a lower temperature for a shorter time. Given the selection of these conditions, expected physical and mechanical properties for biomedical $\mathrm{Si}_{3} \mathrm{~N}_{4}$ were: average density $\geq 3.25 \mathrm{~g} / \mathrm{cc}$ (i.e., $>99.4 \%$ ); and average flexural strength above 1,000 MPa.

For the larger Taguchi $\mathrm{L}_{18}$ experimental array, the Ube SN-E10 raw material was exclusively employed. The experiment examined both the nominal and a range of conditions (high and low) for binder composition, pre-sintering, sintering, and HIPing. Note 
Citation: McEntire, BJ et al. (2016) Processing and Characterization of Silicon Nitride Bioceramics. Bioceram Dev Appl 6: 093. doi:10.4172/20905025.100093

Page 5 of 9

particularly that time was not examined as a part of this study based on the prior work. It was held constant for these tests so that effects of the remaining parameters could be readily examined. The results of this study are presented in Table 3a. ANOVA results are provided in Tables $3 \mathrm{~b}$ and $3 \mathrm{c}$. There are several interesting observations from these data. First, all processing conditions gave excellent densities, both sintered and HIPed. The average sintered and HIPed densities for all conditions were $3.237 \mathrm{~g} / \mathrm{cc}(99.29 \%)$ and $3.258 \mathrm{~g} / \mathrm{cc}(99.94 \%)$, respectively. Second, although there are observable differences in flexural strength, preferred conditions provided values comparable to those obtained in earlier studies. Note particularly that lower firing temperatures gave the best values (i.e., an average of $950 \mathrm{MPa}$ ). This was likely the result of a reduction in average grain size associated with the lower temperature. Weibull modulus and characteristic Weibull strength were also compiled from the individual data (not shown). Preferred conditions yielded an average modulus value of $>10.0$ and characteristic strength in excess of 1,000 MPa. Several ANOVAs were conducted using the flexural strength data of Table $3 \mathrm{a}$, including an
$\mathrm{L}_{18}$ analysis of all conditions (i.e., Table $3 \mathrm{~b}$ ) and a separate $\mathrm{L}_{6}$ analysis which excluded an examination of pre-sintering conditions (i.e., Table 3c). These analyses suggested that three of the experimental factors were significant $(\mathrm{p} \leq 0.05)$ :

(1) Sintering temperature;

(2) HIP temperature; and

(3) Pre-sinter condition.

There were no observed interactive effects between any of the variables. It is especially important to note that HIP pressure (within the range studied) and binder composition had essentially no effect. The ANOVA of Table $3 \mathrm{~b}$ for flexural strength suggests sintering temperature had the most effect (outside of experimental error). This is not surprising, given that most of the microstructural development occurs during the early stages of densification. The subsequent hotisostatic press operation only eliminates closed porosity and uniformly coarsens the microstructure.

\begin{tabular}{|c|c|c|c|c|c|c|c|}
\hline Organics & Pre-Sinter & Sinter Temp. & HIP Temp. & HIP Pressure & Sinter Density (g/cc) & HIP Density (g/cc) & Flexural Strength $(\mathrm{MPa})$ \\
\hline \multirow{9}{*}{ No. 1} & \multirow{3}{*}{ High in N2 } & Low & Low & High & $3.234 \pm 0.003$ & $3.262 \pm 0.006$ & $935 \pm 223$ \\
\hline & & Middle & Middle & Middle & $3.237 \pm 0.002$ & $3.260 \pm 0.005$ & $964 \pm 203$ \\
\hline & & High & High & Low & $3.238 \pm 0.005$ & $3.262 \pm 0.008$ & $796 \pm 96$ \\
\hline & \multirow{3}{*}{ Low in Vacuum } & Middle & High & High & $3.239 \pm 0.001$ & $3.259 \pm 0.013$ & $859 \pm 107$ \\
\hline & & High & Low & Middle & $3.241 \pm 0.001$ & $3.262 \pm 0.003$ & $835 \pm 136$ \\
\hline & & Low & Middle & Low & $3.234 \pm 0.002$ & $3.260 \pm 0.01$ & $958 \pm 138$ \\
\hline & \multirow{3}{*}{ None } & High & Middle & High & $3.236 \pm 0.003$ & $3.262 \pm 0.008$ & $789 \pm 202$ \\
\hline & & Low & High & Middle & $3.229 \pm 0.003$ & $3.262 \pm 0.005$ & $849 \pm 193$ \\
\hline & & Middle & Low & Low & $3.236 \pm 0.002$ & $3.259 \pm 0.004$ & $937 \pm 76$ \\
\hline \multirow{9}{*}{ No. 2} & \multirow{3}{*}{ High in N2 } & Low & Low & High & $3.234 \pm 0.007$ & $3.245 \pm 0.003$ & $948 \pm 105$ \\
\hline & & Middle & Middle & Middle & $3.238 \pm 0.005$ & $3.257 \pm 0.010$ & $930 \pm 147$ \\
\hline & & High & High & Low & $3.245 \pm 0.001$ & $3.250 \pm 0.007$ & $825 \pm 80$ \\
\hline & \multirow{3}{*}{ Low in Vacuum } & Middle & High & High & $3.240 \pm 0.002$ & $3.253 \pm 0.010$ & $835 \pm 90$ \\
\hline & & High & Low & Middle & $3.243 \pm 0.002$ & $3.265 \pm 0.004$ & $857 \pm 87$ \\
\hline & & Low & Middle & Low & $3.233 \pm 0.004$ & $3.268 \pm 0.005$ & $983 \pm 130$ \\
\hline & \multirow{3}{*}{ None } & High & Middle & High & $3.239 \pm 0.011$ & $3.253 \pm 0.011$ & $779 \pm 117$ \\
\hline & & Low & High & Middle & $3.225 \pm 0.004$ & $3.247 \pm 0.008$ & $872 \pm 74$ \\
\hline & & Middle & Low & Low & $3.236 \pm 0.021$ & $3.260 \pm 0.006$ & $924 \pm 96$ \\
\hline
\end{tabular}

Sample Sizes for each condition: Density, $n=5$; Flexural Strength, $n=25$ to 45

Table 3a: Taguchi $L_{18}$ experiment examining the effects of binder composition, pre-sintering, sintering, and hot-isostatic pressing conditions on physical and mechanical properties of biomedical $\mathrm{Si}_{3} \mathrm{~N}_{4}$.

\begin{tabular}{|c|c|c|c|c|c|c|}
\hline Source & ss & df & MS & $\mathbf{F}$ & $\mathbf{P}$ & $\%$ Contribution \\
\hline Powder Composition & 2866 & 1 & 2866 & 0.156 & 0.693 & $0.03 \%$ \\
\hline Pre-Sinter Condition & 270512 & 2 & 135256 & 7.364 & 0.001 & $2.98 \%$ \\
\hline Sinter Temperature & 1145100 & 2 & 572550.1 & 31.172 & 0 & $12.61 \%$ \\
\hline HIP Temperature & 582367.1 & 2 & 291183.5 & 15.853 & 0 & $6.41 \%$ \\
\hline HIP Pressure & 29418.3 & 2 & 14709.2 & 0.801 & 0.45 & $0.32 \%$ \\
\hline $\mathrm{BC}$ & 0 & 4 & 0 & 0 & 1 & $0.00 \%$ \\
\hline $\mathrm{BCD}$ & 0 & 8 & 0 & 0 & 1 & $0.00 \%$ \\
\hline BCE & 0 & 8 & 0 & 0 & 1 & $0.00 \%$ \\
\hline $\mathrm{BD}$ & 0 & 4 & 0 & 0 & 1 & $0.00 \%$ \\
\hline $\mathrm{BDE}$ & 0 & 8 & 0 & 0 & 1 & $0.00 \%$ \\
\hline $\mathrm{BE}$ & 0 & 4 & 0 & 0 & 1 & $0.00 \%$ \\
\hline$C D$ & 0 & 4 & 0 & 0 & 1 & $0.00 \%$ \\
\hline $\mathrm{CDE}$ & 0 & 8 & 0 & 0 & 1 & $0.00 \%$ \\
\hline CE & 0 & 4 & 0 & 0 & 1 & $0.00 \%$ \\
\hline $\mathrm{DE}$ & 0 & 4 & 0 & 0 & 1 & $0.00 \%$ \\
\hline Error & 7053180 & 384 & 18367.66 & & & $77.65 \%$ \\
\hline Total & 9083443 & 449 & & & & \\
\hline
\end{tabular}

Table 3b: $L_{18}$ ANOVA for powder composition, pre-sinter, sinter and hip processes-verification experiment. 
Citation: McEntire, BJ et al. (2016) Processing and Characterization of Silicon Nitride Bioceramics. Bioceram Dev Appl 6: 093. doi:10.4172/20905025.100093

Page 6 of 9

\begin{tabular}{|c|c|c|c|c|c|}
\hline Source & SS & df & MS & F & Pontribution \\
\hline Powder Composition & 87.6 & 1 & 87.6 & 0.005 & 0.945 \\
\hline Sinter Temperature & 921158.7 & 2 & 460579.3 & $0.00 \%$ \\
\hline HIP Temperature & 0 & 2 & 0 & 0 & 0 \\
\hline HIP Pressure & 0 & 2 & 0 & 0 & 0 \\
\hline BC & 0 & 4 & 0 & $0.52 \%$ & 0 \\
\hline Error & 2551791 & 138 & 18491.24 & & $0.00 \%$ \\
\hline Total & 3473037 & 149 & & \\
\hline
\end{tabular}

Table 3c: $L_{6}$ ANOVA for powder composition, pre-sinter, sinter, and hip processes - verification experiment.

Since the observed results of Table 3 a suggested that an intermediate pre-sinter condition in $\mathrm{N}_{2}$ was preferred, the $\mathrm{L}_{6}$ ANOVA was completed to determine which of the remaining factors were important (i.e., Table 3c). This analysis indicated that sintering temperature was the most important factor $(\mathrm{p} \leq 0.05)$. Binder composition, HIP temperature, and pressure played no role, and there were no other interactive effects.

The results of these two Taguchi studies confirmed observations conducted in the earlier validation tests. Correlation and trend line analyses were subsequently performed using data from all of the experimental conditions [52]. The results indicated that a fairly broad range in sintering temperatures provided adequate flexural strength. As expected, the highest predicted strengths $(\sim 1,090 \mathrm{MPa})$ occurred for the lowest sintering temperature.

As the sintering temperature increased, strength decreased regardless of other process factors. At a constant and relatively low sintering temperature, successively higher HIP temperatures also resulted in decreased strengths. Both are likely due to microstructural coarsening. The data suggest that the lowest sintering and HIP temperatures are preferred, but also indicate that the acceptable range was fairly broad (i.e., $\pm 40^{\circ} \mathrm{C}$ ). There were very little observed differences between various HIP pressures. The data suggested that a lower HIP pressure is preferred, but the acceptable range is inclusive of all conditions studied within the experiments.

\section{Process verification}

Final selection of process parameters and ranges were determined pursuant to completion of the validation experiments described in the previous section. Multiple production powder lots were subsequently produced. From the powder lots, both test-bars and actual production components were prepared and evaluated to verify the efficacy of the selected conditions. Critical outcomes included the attainment of required dimensions and tolerances on actual components, and achievement of minimum physical and mechanical properties on co-processed test-bars. Powder compaction was analyzed for each production powder lot, including assessments for green density and linear shrinkage at various compaction pressures. Tight controls over press density were necessary to meet final dimensional tolerances. However, minor differences between various powder lots were compensated by slight changes in compaction pressure. Results for four production lots are presented in Figures $4 \mathrm{a}$ and $4 \mathrm{~b}$, respectively. These density and shrinkage curves provide important engineering information for predicting as-fired part dimensions. Empirical relationships correlating green density and shrinkage have been extensively investigated and are highly predictable [32,54]. Both linear shrinkage and green density can be adequately modeled using logarithmic functions of compaction pressure. Note that excellent correlation coefficients $(>0.99)$ for these empirical equations were achieved. Using the engineering information of Figures $4 \mathrm{a}$ and $4 \mathrm{~b}$, specific press parameters and dimensions were chosen for
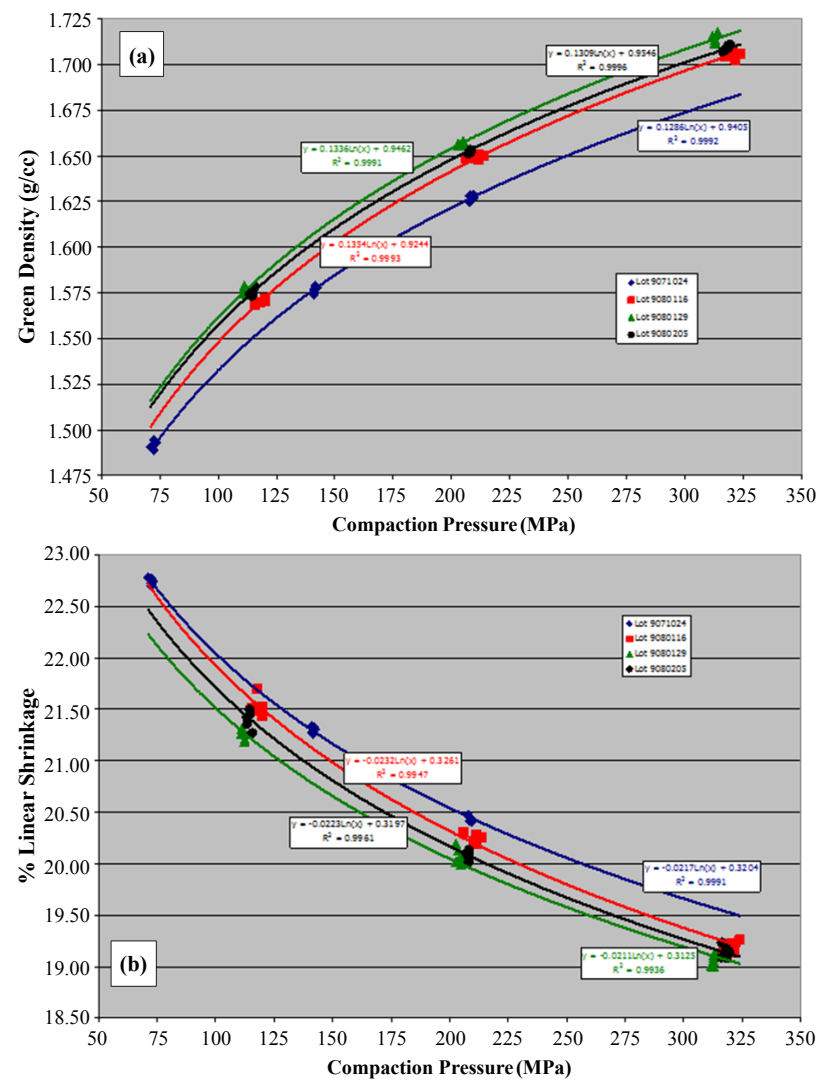

Figure 4: Compaction and shrinkage behavior of four production powder lots used for biomedical $\mathrm{Si}_{3} \mathrm{~N}_{4}$ intervertebral spinal spacers in (a) and (b), respectively.

green forming operations (i.e., pressing and green machining) of intervertebral spinal spacers. Statistical process controls (SPC) were implemented on pressed ware and green machined components [5557]. Sequentially collected data on the weight and height of each part were used to calculate green densities and predict linear shrinkage. Tracking of linear shrinkage was used to monitor and adjust the pressing operation to ensure appropriate dimensional control over finished components. These SPC controls are shown in Figures $5 \mathrm{a}$ and $5 \mathrm{~b}$ using $X$-bar $R$-charts and process capability analyses (i.e., $\mathrm{Cp}$ and $\mathrm{C} p k$ ), respectively. While these controls were used on every lot, only one component production work order comprising approximately 250 individual pieces is shown as a representative example in Figures $5 \mathrm{a}$ and $5 \mathrm{~b}$. When slight out of control conditions occurred (according to SPC rules) [58], this information was immediately available to the press operator in order to make minor adjustments to either part weight or height and bring the process back within control. The Cpk analysis demonstrated excellent overall process capability. Target shrinkage for 

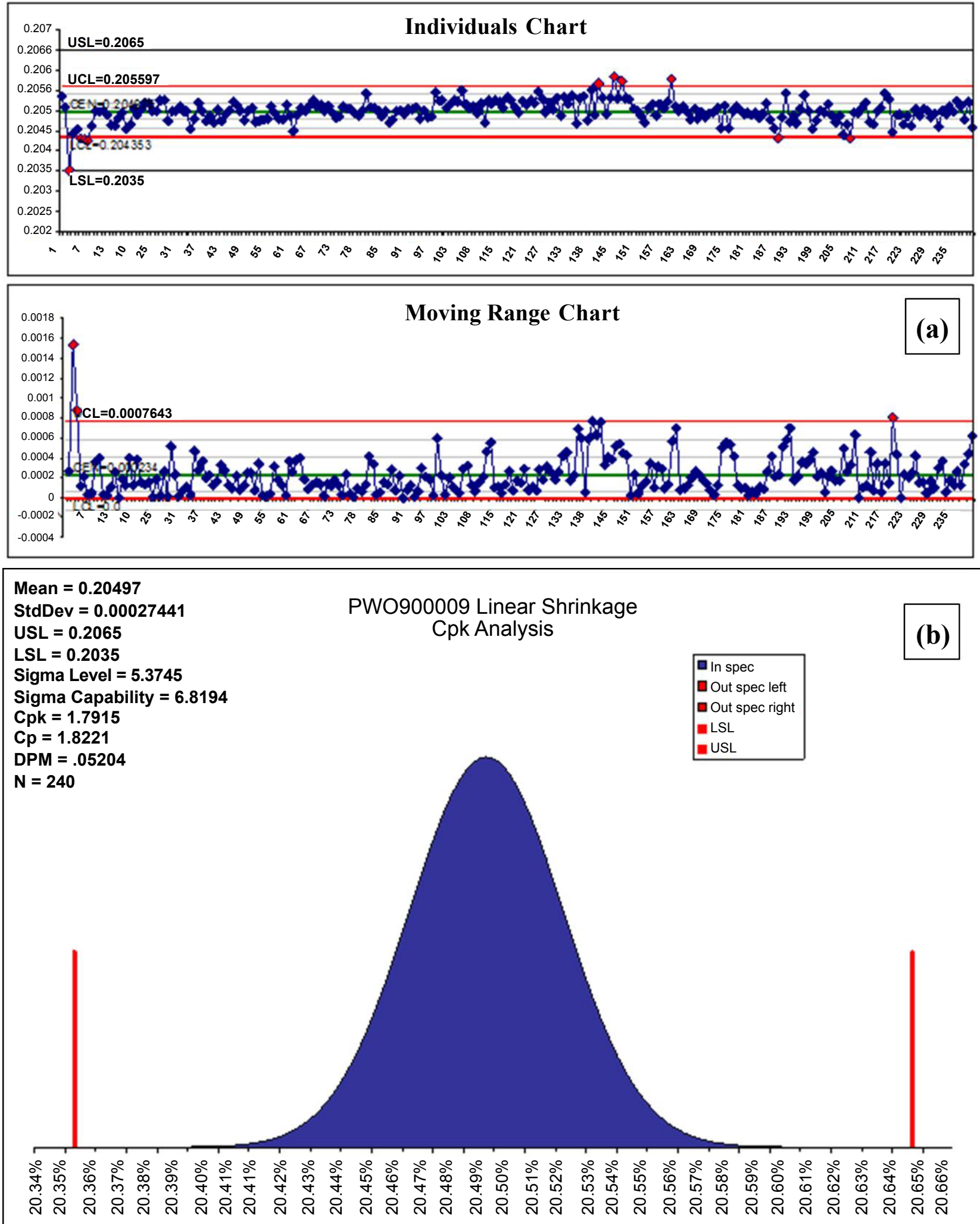

Figure 5: Statistical process control charts and process capability indices for a typical production lot of intervertebral spinal spacers from a biomedical $\mathrm{Si}_{3} \mathrm{~N}_{4}$ in $(a)$ and (b), respectively. 
Citation: McEntire, BJ et al. (2016) Processing and Characterization of Silicon Nitride Bioceramics. Bioceram Dev Appl 6: 093. doi:10.4172/20905025.100093

this specific lot was $20.5 \%$ at a compaction pressure of $\sim 207 \mathrm{MPa}$, with the range of acceptable shrinkage varying between $20.35 \%$ and $20.65 \%$, yielding a Cpk value of greater than 1.79 (i.e, a sigma level of 5.4). Processes are said to be in good control if their $\mathrm{C} p k$ value is greater than 1.33. All final component features were then machined or laser etched into the pressed blanks, leaving them with the precise amount of green stock to shrink to their final dimensions during the firing processes.

While forming operations primarily defined dimensional features and tolerances, physical and mechanical properties were the product of powder composition and firing processes. Since the composition for this $\mathrm{Si}_{3} \mathrm{~N}_{4}$ biomaterial was fixed, conditions selected for pre-sintering, sintering, and HIPing principally determined these characteristics, as demonstrated by the validation results given previously. Density, flexural strength, and fracture toughness data were compiled from co-processed test specimens from production powder lots. Provided in Figure 6 are density results compiled from 194 sequentially manufactured component batches comprised of 8 different powder lots. Component batches are subsets of production powder lots and are defined by their unique part numbers. They can range in quantity from as small as eight to several hundred pieces; whereas production powder lots can range from 150 to $300 \mathrm{~kg}$. Density measurements were performed on samples from each component batch, with a lower specification limit set at $\geq 3.23 \mathrm{~g} / \mathrm{cc}(98.75 \%)$. No component batches fell below this minimum, with the average being $3.254 \mathrm{~g} / \mathrm{cc}$ for all 194 batches. Mechanical properties, including flexural strength and fracture toughness, were assessed for all powder lots. Figure 7

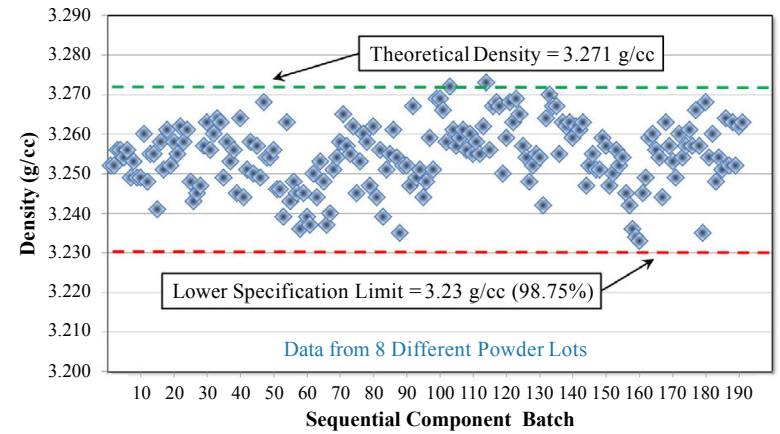

Figure 6: Mass density results from 194 sequential component batches comprised of eight different powder lots of a biomedical $\mathrm{Si}_{3} \mathrm{~N}_{4}$.

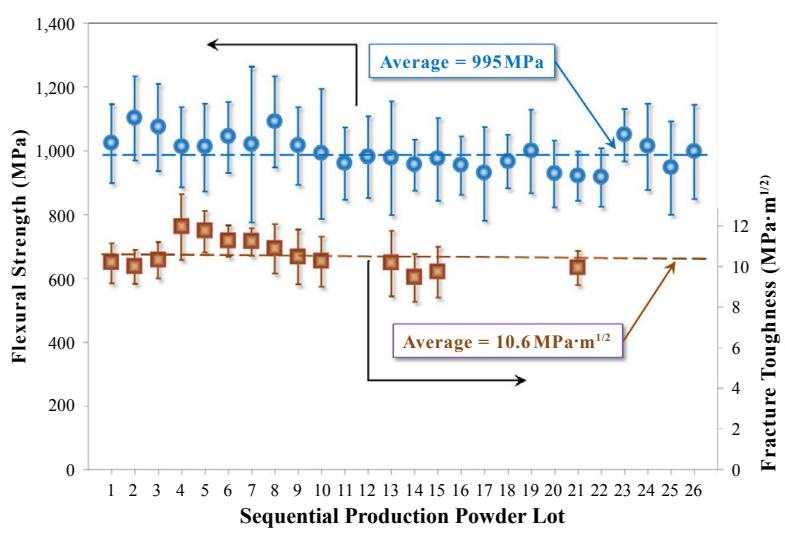

Figure 7: Flexural strength and fracture toughness evaluations for sequentially produced production $\mathrm{Si}_{3} \mathrm{~N}_{4}$ powder lots. presents results from 26 different sequentially produced powder lots. Flexural strengths were acquired on all lots, while fracture toughness measurements were acquired only for the first ten lots, and sampled for selected lots thereafter. Average results for flexural strength and fracture toughness were $995 \mathrm{MPa}$ and $10.6 \mathrm{MPa} \cdot \mathrm{m}^{1 / 2}$, respectively, with the range of individual lots falling within one standard deviation of the overall mean. These results demonstrate reasonable repeatability and control for mechanical properties within the manufacturing process.

\section{Conclusion}

A dedicated and vertically integrated factory established for the purpose of manufacturing intervertebral spinal spacers from a biomedical $\mathrm{Si}_{3} \mathrm{~N}_{4}$ was subjected to process validation and verification in accordance with regulatory requirements. Efficient Taguchi fractional factorial designed experiments were utilized to assess and correlate critical process parameters to product properties. Results demonstrated that selection of raw materials, particularly the $\mathrm{Si}_{3} \mathrm{~N}_{4}$ powder source, and firing conditions had the most effect on physical and mechanical properties, with binder composition and compaction pressure affecting dimensional characteristics. Using these experiments, process parameters were subsequently selected to provide acceptable and consistent results for multiple production powder lots and individual component batches. It was demonstrated that the adopted processes were capable of achieving tight statistical controls over dimensions (i.e., Cpk and sigma level of $>1.79$ and $~ 5.4$, respectively), with average flexural strengths and fracture toughness values of $995 \mathrm{MPa}$ and 10.6 $\mathrm{MPa} \cdot \mathrm{m}^{1 / 2}$, respectively. Manufacturing of biomedical $\mathrm{Si}_{3} \mathrm{~N}_{4}$ ceramics has been conducted since 2008 using the processes and parameters described herein.

\section{References}

1. Riley FL (2000) Silicon nitride and related materials. J Am Ceram Soc 83: 245-265.

2. Parr NL, Martin GF, May ERW (1960) Preparation, microstructure, and mechanical properties of silicon nitride. In Spec Ceram, Edt by Popper P, Heywood Press, New York, NY, pp: 102-135.

3. Deeley GG, Herbert JM, Moore NC (1961) Dense silicon nitride. Pow Metal 4 145-151.

4. Lange FF (2006) The sophistication of ceramic science through silicon nitride studies. J Ceram Soc Japan 114: 873-879.

5. Tajima $Y$, Urashima K, Watanabe $M$, Matsuo $Y$ (1988) Fracture toughness and microstructure evaluation of silicon nitride ceramics. In Ceram Trans, Am Cer Soc Press, Westerville, OH, pp: 1034-1041.

6. Li CW, Yamanis J (1989) Super-tough silicon nitride with r-curve behavior Ceram Eng Sci Proc 10: 632-645.

7. Petzow G, Hermann M (2002) Silicon nitride ceramics. In High Perf. Non-Oxide Ceram II, Springer Press, Berlin Heidelberg, Germany, pp: 47-167.

8. Hampshire S (1991) Engineering properties of nitrides. In Eng Mater Handbook ASM International, Materials Park, OH. pp: 812-820

9. Wittmer E, Doshi D, Paulson TE (1992) Development of self-reinforced composites. In Ceram Eng Sci Proc pp: 907-917.

10. Tajima $Y$ (1992) Development of high performance silicon nitride ceramics and their applications. In Silicon Nitride - Sci Technol Adv MRS Symp Proc, Edt by Chen IW, Cambridge Univ Press, Pittsburg, PA, p. 189.

11. Hoffmann MJ (1995) Relationship between microstructure and mechanical properties of silicon nitride ceramics. Pure Appl Chem 67: 939-946.

12. Becher PF, Sun EY, Plucknett KP, Alexander KB, Hsueh C, Westmoreland CG, Microstructural design of silicon nitride with improved fracture toughness: I, Effects of grain shape and size. J Am Ceram Soc 81: 2821-2830.

13. Sun EY, Becher PF, Plucknett KP, Hsueh CH, Alexander KB, et al. (1998) Microstructural design of silicon nitride with improved fracture toughness: II Effects of yttria and alumina additives. J Am Ceram Soc 81: 2831-2840. 
Citation: McEntire, BJ et al. (2016) Processing and Characterization of Silicon Nitride Bioceramics. Bioceram Dev Appl 6: 093. doi:10.4172/20905025.100093

14. Bressiani JC, Izhevskyi V, Bressiani AHA (1999) Development of the microstructure of the silicon nitride based ceramics. Mater Res 2: 165-172

15. Prescher T, Heinrich JG (2004) Microstructure-properties correlation of continuously sintered silicon nitride. Ceram forum Int 81: E37-E41.

16. Riley FL (1996) Applications of silicon nitride ceramics. Key Eng Mater 122 479-488.

17. Willmann G (2001) Improving bearing surfaces of artificial joints. Adv Eng Mater 3: 135-141.

18. Howlett CR, McCartney E, Ching W (1989) The effect of silicon nitride ceramic on rabbit skeletal cells and tissue. Clin Orthop Relat Res 244: 293-304.

19. Kue R, Sohrabi A, Nagle D, Frondoza C, Hungerford D (1999) Enhanced proliferation and osteocalcin production by human osteoblast-like MG63 cells on silicon nitride ceramic discs. Biomaterials 20: 1195-2001.

20. Sorrell CC, Hardcastle PH, Druitt RK, Howlett CR, McCartney ER (2004) Results of 15-year clinical study of reaction bonded silicon nitride intervertebral spacers. Proc 7th World Biomater Conference, 1872

21. Bal BS, Garino J, Ries M, Rahaman MN (2006) Ceramic materials in total join arthroplasty. Semin Arthroplasty 17: 94-101.

22. Rahaman MN, Yao A, Bal BS, Garino JP, Ries MD (2007) Ceramics for prosthetic hip and knee joint replacement. J Am Ceram Soc 90: 1965-1988.

23. Clarke IC, Willmann G (1994) Structural ceramics in orthopedics. In Cameron Hu pp: 203-252.

24. Bal BS, Rahaman M (2011) The rationale for silicon nitride bearings in orthopaedic applications. INTEC pp: 421-432.

25. Bal BS, Rahaman MN (2012) Orthopedic applications of silicon nitride ceramics. Acta Biomater 8: 2889-2898.

26. Lincoln JE (2012) Overview of the US FDA GMPS: Good Manufacturing Practice (GMP)/Quality System (QS) regulation (21 CFR Part 820). J Valid Technol 18: 17-22.

27. Wötting G, Ziegler G (1984) Influence of powder properties and processing conditions on microstructure and mechanical properties of sintered $\mathrm{Si}_{3} \mathrm{~N}_{4}$. Ceram Int 10: 18-22.

28. Yang JF, Ohji T, Niihara K (2000) Influence of yttria-alumina content on sintering behavior and microstructure of silicon nitride ceramics. J Am Ceram Soc 83: 2094-2096.

29. Iturriza I, Castro F, Fuentes M (1989) Sinter and sinter-hip of silicon nitride ceramics with yttria and alumina additions. J Mater Sci 24 2047-2056.

30. Liu XJ, Huang ZY, Pu XP, Sun XW, Huang Z (2005) LP influence of planetary high-energy ball milling on microstructure and mechanical properties of silicon nitride ceramics. J Am Ceram Soc 88: 1323-1326.

31. Kamiya H, Isomura K, Jimbo G, Jun-Ichiro T (1995) Powder processing for the fabrication of $\mathrm{Si}_{3} \mathrm{~N}_{4}$ ceramics: Influence of spray-dried granule strength on pore size distribution in green compacts. J Am Ceram Soc 78: 49-57.

32. McEntire BJ (1991) Dry pressing. In: Eng Mater Handbook, Schneider SJJ (ed.) ASM International, Metals Park, OH, pp: 141-146.

33. Naito N, DeJonghe LC, Rahaman MN (1990) Pore size distribution during compaction and early stage sintering of silicon nitride. J Mater Sci 25: 1686-1689.

34. Su B, Dhara S, Wang L (2008) Green ceramic machining: a top-down approach for the rapid fabrication of complex-shaped ceramics. J Eur Ceram Soc 28: 2109-2115.

35. Butt DP, Albert D, Taylor TN (1996) Kinetics of thermal oxidation of silicon nitride powders. J Am Ceram Soc 79: 2809-2814.

36. Natahsohn S, Pasto AAE, Rourke WJW (1993) Effect of powder surface modifications on the properties of silicon nitride ceramics. J Am Ceram Soc 76: $2273-2284$.

37. Ziegler A, McNaney JM, Hoffmann MJ, Ritchie RO (2005) On the effect of local grain-boundary chemistry on the macroscopic mechanical properties of a highpurity $\mathrm{Y}_{2} \mathrm{O}_{3}-\mathrm{Al}_{2} \mathrm{O}_{3}$-containing silicon nitride ceramic: role of oxygen. J Am Ceram Soc 88: $1900-1908$

38. Singhal SC (1976) Thermodynamics and kinetics of oxidation of hot-pressed silicon nitride. J Mater Sci 11: 500-509.
39. Ziegler G, Heinrich J, Wötting G (1987) Relationships between processing microstructure and properties of dense and reaction-bonded silicon nitride. $J$ Mater Sci 22: 3041-3086.

40. Paccaud O, Derro A (2000) Silicon carbide coating by reactive pack cementation - part II: Silicon monoxide/carbon reaction. Chem Vap Depos 6: 41-50.

41. Herrmann M, Goeb O (2001) Colour of gas-pressure-sintered silicon nitride ceramics part I. Experimental data. J Eur Ceram Soc 21: 303-314.

42. Goto Y, Ohnuma Y (2011) Weight loss and gas evolution during sintering of silicon nitride powders synthesized by silica reduction and imide decomposition. J Mater Res 13: 3468-3472.

43. Hwang S, Becher P, Lin H (1997) Desintering process in the gas-pressure sintering of silicon nitride. J Am Ceram Soc 80: 329-335.

44. Messier DR, Riley FL, Brook RJ (1978) The $\alpha / \beta$ silicon nitride phase transformation. J Mater Sci 13: 1199-1205.

45. Suttor D, Fischman GS (1992) Densification and sintering kinetics in sintered silicon nitride. J Am Ceram Soc 75: 1063-1067.

46. Kawaoka H, Kusunose T, Choa Y, Sekino T, Niihara K (2001) Precise property control in silicon nitride ceramics by $\alpha / \beta$ phase ratio control. J Ceram Process Res 2: 51-53.

47. Weisse B, Affolter C, Koller RE, Stutz A (2010) Proof testing of ceramic femoral heads for hip joint implants. Proc Inst Mech Eng H 224: 1051-1059.

48. Mollah AH (2005) Application of failure mode and effect analysis (FMEA) for process risk assessment. Bioprocess Int 3: 12-20.

49. Taguchi G (1986) Introduction to quality engineering: designing quality into products and processes. 4: 198.

50. McEntire BJ, Hengst RR, Collins WT, Taglialavore AP, Yeckley RL (1993) Ceramic component processing development for advanced gas turbine engines. J Eng Gas Turbines Power 115: 1-8.

51. Taguchi G, Clausing D (1990) Robust quality. Harv Bus Rev 68: 65-75.

52. Maghsoodloo S, Ozdemir G, Jordan V, Huang CH (2004) Strengths and limitations of Taguchi's contributions to quality, manufacturing, and process engineering. J Manuf Syst 23: 73-126.

53. Hirao K, Nagaoka T, Brito ME, Kanzaki S (1994) Microstructure control of silicon nitride by seeding with rodlike $ß$-silicon nitride particles. J Am Ceram Soc 77: 1857-1862.

54. McEntire B (1983) Tooling design for wet-bag isostatic pressing. In: Form Ceram Adv Ceram, Am Cer Soc Press, Columbus, OH, pp: 16-31.

55. De Gijs Bertus W (2006) Process control in the manufacture of ceramics. In Mater Sci Technol. 104: 74-80

56. Carson MA, Fryburg GA, Makar FB (1986) Statistical process contro techniques applied to the manufacture of high technology ceramics. In Mater Equip Whitewares Ceram Eng Wci Proc, John Wiley \& Sons, New York, NY, pp: 1312-1326

57. Ryan TP (2011) Statistical methods for quality improvement (3rd Ed). John Wiley \& Sons.

58. Zarandi M, Alaeddini A, Turksen I (2008) A hybrid fuzzy adaptive sampling-run rules for shewhart control charts. Inf Sci 178: 1152-1170.

Citation: McEntire, BJ et al. (2016) Processing and Characterization of Silicon Nitride Bioceramics. Bioceram Dev Appl 6: 093. doi:10.4172/2090-5025.100093 